\title{
Ammonite-benthic Foraminifera turnovers across the Lower-Middle Jurassic transition in the Lusitanian Basin (Portugal) ${ }^{\S}$
}

\author{
Maria Helena Paiva Henriques ${ }^{\mathrm{a}, *}$, Maria Luisa Canales ${ }^{\mathrm{b}}$ \\ ${ }^{a}$ Department of Earth Sciences and Geosciences Centre, Faculty of Sciences and Technology, University of Coimbra; Largo Marquês de Pombal, $3000-272$ \\ Coimbra, Portugal \\ ${ }^{\mathrm{b}}$ Department of Paleontology, Facultad de Ciencias Geológicas, Universidad Complutense de Madrid, José Antonio Novais, 2 , 28040 Madrid, Spain
}

\begin{abstract}
A B S T R A C T

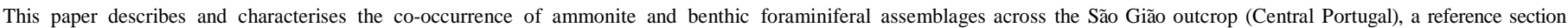

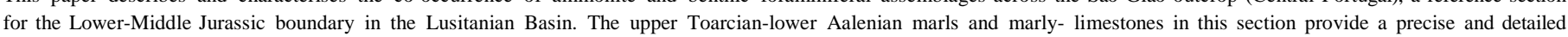

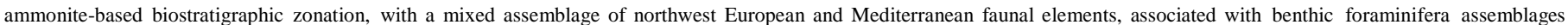

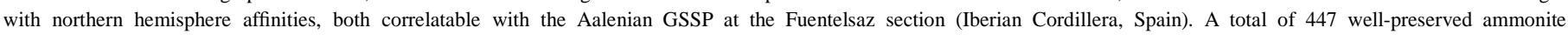

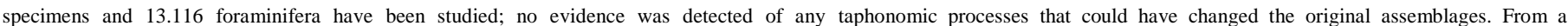

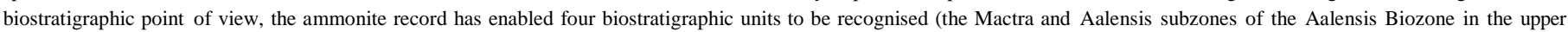

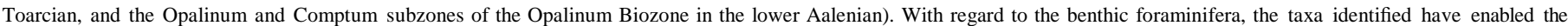

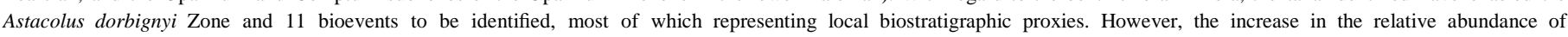

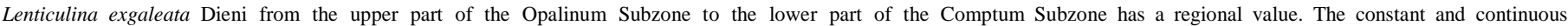

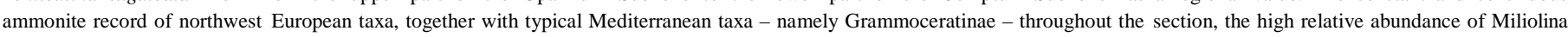

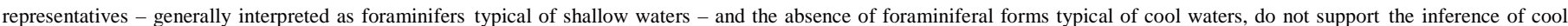
seawater temperatures attributed to the Early Aalenian, or the global character of the "Comptum cooling event", at least with reference to the Lusitanian Basin.
\end{abstract}

Keywords:

Ammonite-benthic Foraminifera biostratigraphy,Lower-Middle Jurassic Toarcian, Aalenian Lusitanian Basin Faunal turnover, “Comptum cooling event”

\section{Introduction}

Ammonites are the best fossil group for dating Jurassic marine sediments, but when these fossils are poorly preserved, scarce or almost impossible to obtain (e.g., in core samples), alternative biostratigraphic scales based on other fossil groups are needed. In recent decades, there have been some attempts to establish biostratigraphic scales based on benthic foraminifera. The preci- sion and validity of such scales is greater when they can be calibrated with accurate biostratigraphic charts based on ammo- nites, as done in this work. The stratigraphic range of most of the Jurassic foraminiferal species is relatively wide; therefore, identification of bioevents such as first occurrences (First Appearance Datum, FAD), last occurrences (Last Appearance

\footnotetext{
${ }^{\S}$ Corresponding editor: Fabienne Giraud-Guillot.

* Corresponding author. Tel.: +35 1239860510; fax: +35 1239860501

E-mail address: hhenriq@dct.uc.pt(M.H.P.Henriques).
}

Datum, LAD) or noticeable changes in assemblage diversity or in the relative abundance of some taxa, can be a useful biostrati- graphic tool. Hence, the aim of this work is to describe for the first time the detailed co-occurrence of ammonite and benthic foraminiferal assemblages across the Toarcian-Aalenian boundary at the São Gião section (Lusitanian Basin, Central Portugal), and to recognise the corresponding biostratigraphic units, thus contri- buting to a better calibration of the biostratigraphic scale for the Lower-Middle Jurassic boundary on the basis of different fossil groups.

The São Gião section is a classical outcrop of the Lower-Middle Jurassic boundary in the Lusitanian Basin, where previous works on ammonites were carried out by Mouterde et al. (1979) and Caloo-Fortier (1985). It is one of the few areas in Europe where this time interval is represented by an expanded section, showing exceptional exposure conditions along highly fossiliferous marly- limestones sediments approximately 45 m-thick, displaying a continuous record of ammonites. Moreover, the relevance of the 
Grammoceratinae content for palaeobiogeographic reconstruc- tions of the western Tethys (Sandoval et al., 2012a), as well as the significant Pleydellia and Leioceras record, both justified the proposition of the São Gião section as a reference section for the Toarcian-Aalenian boundary in the Lusitanian Basin (Henriques, 1989, 1992, 2000a; Henriques et al., 1996; Goy et al., 2000; Sandoval et al., 2001a; Azerêdo et al., 2003). More recently, other fossil groups in the section have been studied, namely calcareous nannofossils (Henriques and Perilli, 2000), and most particularly benthic foraminifera (Magno et al., 2008; Magno, 2010; Canales et al., 2010). These studies all suggested the importance of analysing the detailed vertical co-occurrence of ammonite and benthic foraminifera assemblages across the ToarcianAalenian boundary at the São Gião section, in order to identify major faunal changes both on macrofossil and microfossil assemblages.

The bioevents recognised in the benthic foraminifera record, accurately calibrated here using ammonite-based biostratigraphic units, represent a proxy that can be used to determinate both the age and depositional environment assigned to core samples (Canales et al., 2010). Moreover, they allow the interpretation of previous data on palaeotemperature changes established for neighbouring basins located around the Iberian Plate, e.g., in the southern and northern palaeomargins (O’Dogherty et al., 2006; Sandoval et al., 2008; Gómez et al., 2009), as well as in more distant, boreal regions such as the Hebrides Basin (Price, 2010), where close relationships between major faunal-flora turnovers and isotopic fluctuations in $\mathrm{d}^{13} \mathrm{C}$ have been recognised (Aguado et al., 2008; Sandoval et al., 2012b).

\section{Geographic and geological settings}

The São Gião section is located in the northern sector of the Lusitanian Basin (Central Portugal), at about $5 \mathrm{~km}$ to the South- Southwest of Cantanhede village, near Zambujal (coordinates: $40818^{0} 12.63^{0} \mathrm{~N}, 8837^{0} 17.58^{0} \mathrm{~N}$; altitude: $100 \mathrm{~m}$; Fig. 1). The section is composed of greyish marly limestones, more or less compact, in regular beds with thicknesses ranging from 0.10 to $0.30 \mathrm{~m}$, alternating with slightly thicker greyish marl beds organised in shallowing- upward units and deposited in an external marine platform environment. The limestone component progressively increases towards the top of this unit, which corresponds to the upper part of the P'o voa da Lomba Formation (upper Toarcianupper Aalenian).

The Póvoa da Lomba Formation was firstly informally defined by Barbosa et al. $(1988,2008)$ as a lithostratigraphic unit named the "Calcários Margosos de Pó voa da Lomba" ("Pó voa da Lomba Marly Limestones”), and later formalised as the Pó voa da Lomba Formation by Azerêdo et al. (2003). It corresponds laterally to the lower part of the Cabo Mondego Formation which outcrops at the west of the basin, the upper part of the Prado Formation outcropping eastwards, and the top of the Fó rnea Formation/base of the Barranco de Zambujal Formation which outcrops in the southeast of the basin (Azerêdo et al., 2003; Fig. 2).
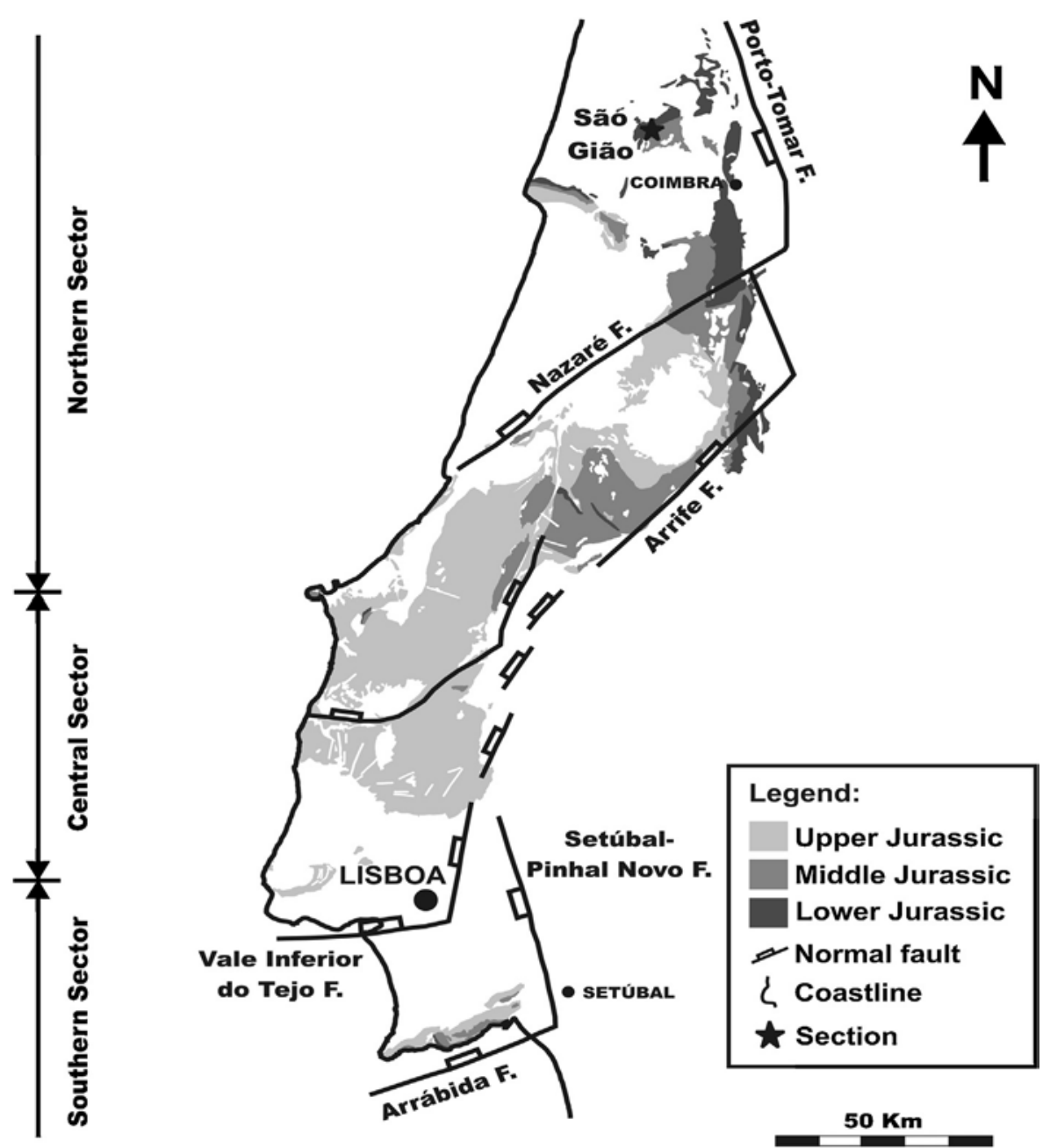

Fig. 1. Geological map of the Lusitanian Basin (West of the Iberian Peninsula) showing the Jurassic outcrops and location of the São Gião section. Modified after Figueiredo (2009). 


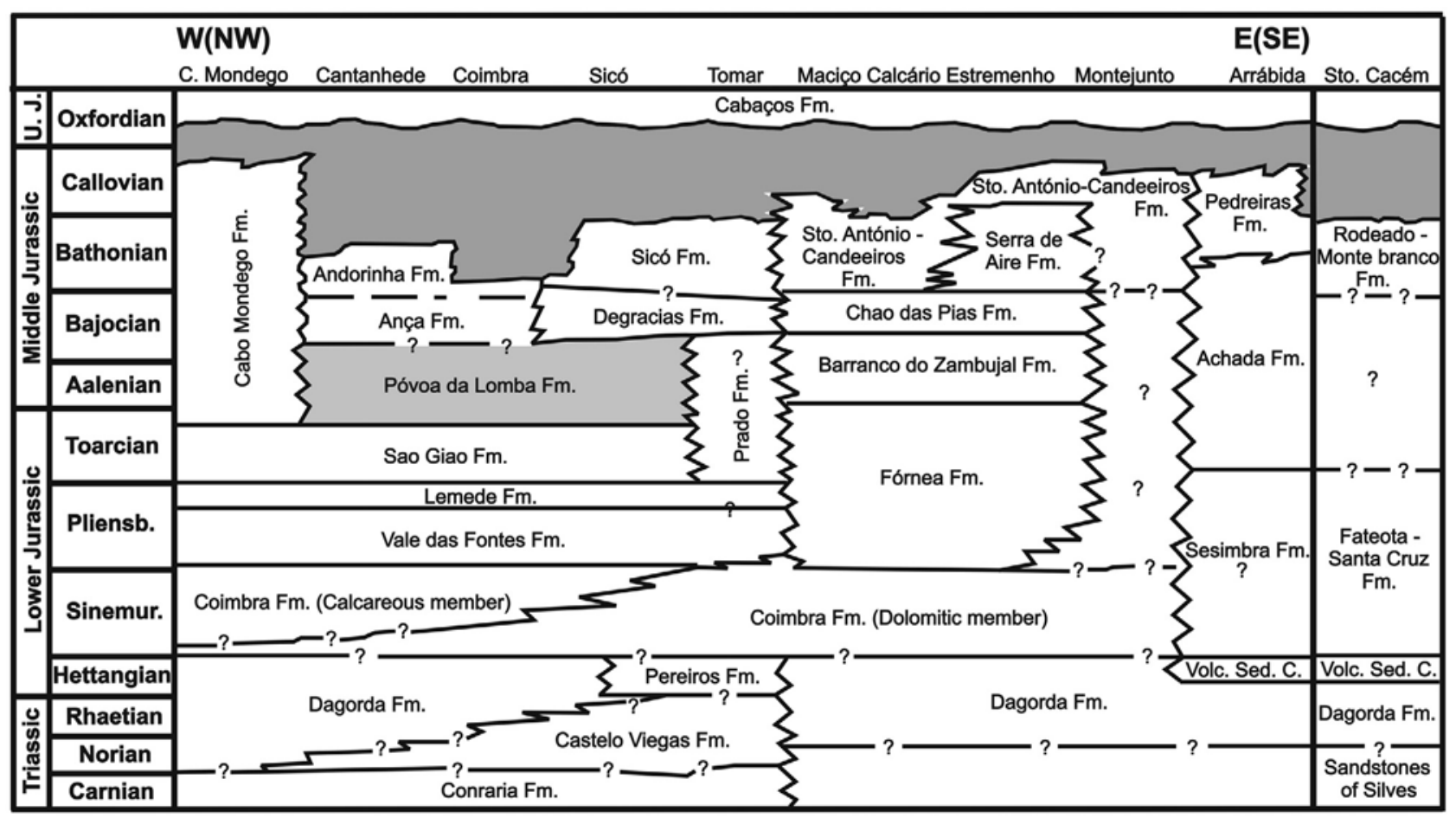

Fig. 2. Synthetic lithostratigraphic chart for the upper Triassic and lower and middle Jurassic of the Lusitanian Basin, showing the position of the São Gião section. Modified after Azerêdo et al. (2003).

\section{Material and methods}

In order to study the ammonite record, 44 successive bed-by- bed samplings were obtained from 36 marly-limestone beds and eight marly beds. A total of 447 ammonite specimens were collected and identified according to the systematic classification proposed by Henriques (1992).

A total of 24 marly beds were sampled for the study of the benthic foraminiferal assemblages, taking into account the thickness of each ammonite subzone. For each sample, $300 \mathrm{~g}$ were processed in the laboratory using a classical methodology involving a mixture of sodium hydroxide, hydrogen peroxide and water for 2-3 days. Following this, the samples were washed over a column of 1.000, 0.500, 0.250, 0.125 and $0.060 \mathrm{~mm}$ mesh sieves. The dry residues were weighed and subsequently picked to obtain the foraminifera using a Wild M-8 binocular microscope. The specimens recovered were classified, at suprageneric and generic rank, using the Loeblich and Tappan (1988) systematic; the Ellis and Messina's (1940-1990) for- aminifera catalogue was consulted for the specific rank classification. Photographs of the figured specimens were taken at the Centro Nacional de Microscopía Electró nica, Universidad Complutense de Madrid (Spain), using a JEOL-JSM 6400 electronic microscope.

The species richness and relative abundances were calculated for both fossil groups. Species richness is understood as the number of species (or other taxonomical category) in a sampling unit, in relation to the total number of identified species (or other taxa). Relative abundances are expressed as percentages, in relation to the total number of specimens obtained in each assemblage. All the ammonite and foraminifera specimens (including the residues of the samples studied) are stored in the Laboratório de Geologia Sedimentar e Registo Fóssil, Departa- mento de Ciências da Terra, Faculdade de Ciências e Tecnologia, University of Coimbra (Portugal).

\section{Taphonomic considerations}

The preservational features of the ammonite assemblages can be characterised according to several taphonomic parameters described for Tmetoceras from Iberia (Ferná ndez Ló pez et al., 1999a, 1999b) and for other ammonites from the Lower Pliensbachian of Portugal (Fernández Ló pez et al., 2000). Marly limestones mainly record resedimented elements, whereas accumulated shells are virtually absent and re-elaborated elements are scarce. Ammonite assemblages are composed of incomplete phragmocones normally filled with sediment and, in general, appear scattered in the sediment, showing no pattern of imbricate or encased grouping. Complete shells are scarce and pyritic internal moulds are only found locally and assigned to marly levels. The degree of ammonite packing estimated by the difference between the number of specimens and the number of fossiliferous levels divided by the number of fossiliferous levels - and the ammonite stratigraphical persistence - i.e., the proportion of fossiliferous levels - presents high values (9.15 and 38\%, respectively), whereas the degree of taphonomic heritage - i.e., the percentage of re-elaborated elements is very low to nil.

The ratio between the amount of preserved elements and the amount of species is high (26.3), making specific diversity, i.e., the inverse ratio, relatively low (0.04); adult shells are scarce. These taphonomic features, by disproving sorting processes involving mechanical transport, support the demic nature of the fossil assemblages, as pointed out by Fern'a ndez Lo' pez and Mele' ndez (1995) for the Phylloceratina and by Fern'a ndez Lo' pez et al. (1999b) for the Tmetoceras of the Iberian basins during the Middle Jurassic. Concerning the benthic foraminifera record, most of the 13,116 specimens recovered are very well preserved. From a taphonomic point of view, only breakages, sedimentary infillings of the chambers, dissolution (partial or even total, as is the case for some representatives of the Ceratobuliminidae Family), distortion and recrystallisation (Herrero and Canales,2 002) wereo bservedi ns ome 


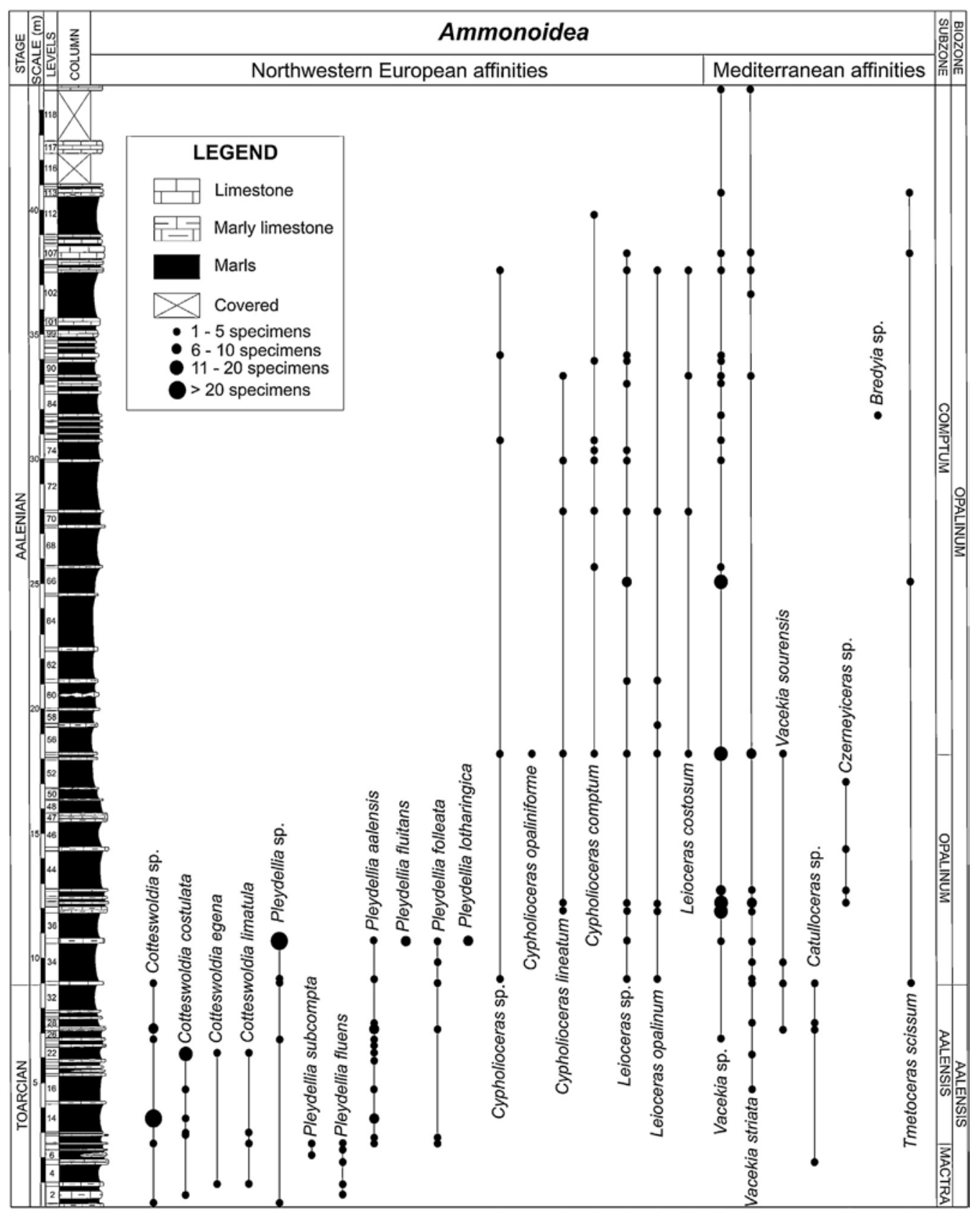

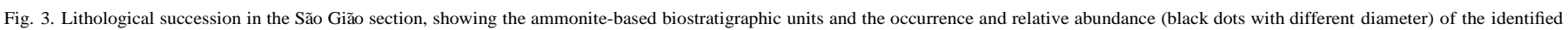
ammonite taxa along the section.

specimens, but no evidence of any alteration of the assemblages can be inferred. The last two studied samples come from harder sediments and, as a consequence, the surface of the specimens appeared to be covered by calcite crusts, thus hindering their taxonomic identification at specific rank.

\section{Results}

The co-occurrence of ammonite and benthic foraminiferal assemblages across the São Gião section provides a precise and detailed ammonite-based biostratigraphic zonation as well as an alternative biostratigraphic scale based on benthic foraminifera. In addition, the identification of bioevents, such as FADs, LADs or noticeable changes in assemblages' species richness or in the relative abundance of some taxa in both fossil groups, may prove to be a useful biostratigraphical proxy. Such bioevents are, so far, considered to be of local application. It is expected that future analyses in the same basin or in other basins will allow for correlations between different sections, based on some of these bioevents. Moreover, the taxonomic composition of the assem- blages and the recognised bioevents in the São Gião section provide relevant palaeoecological data for ongoing discussions on the relationships between major faunal turnovers and palaeotem- peraturechangesduringtheEarly-MiddleJurassictransition.

\subsection{Ammonite and benthic foraminiferal assemblages}

The ammonite record of the São Gião section mainly includes some typical northwest European Grammoceratinae (Catulloceras, Cotteswoldia, Pleydellia) in the upper Toarcian, and Leioceratinae (Leioceras, Cypholioceras) in the lower Aalenian, together with typical Mediterranean Grammoceratinae (Vacekia), Tmetoceratinae 


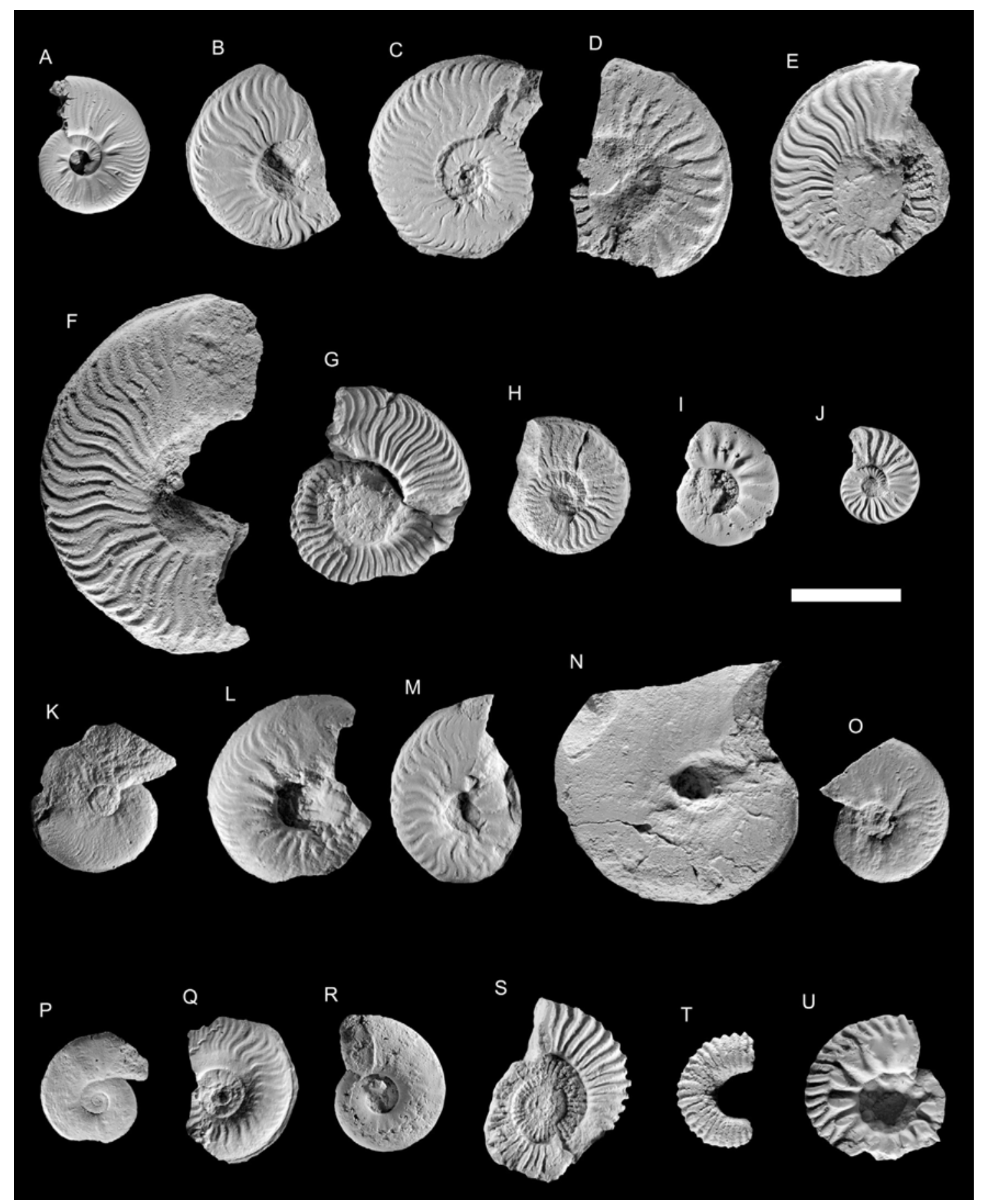

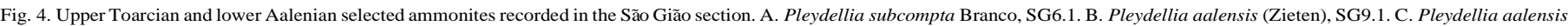

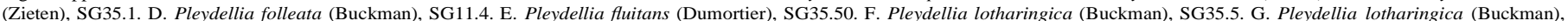

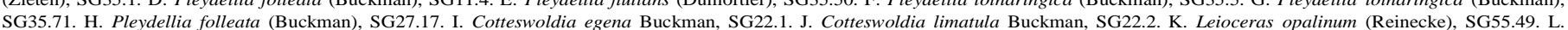

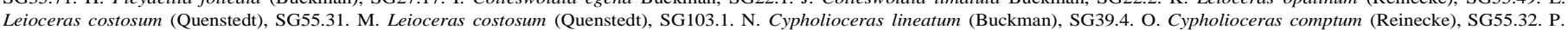

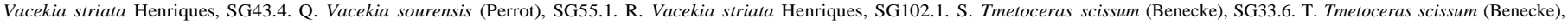

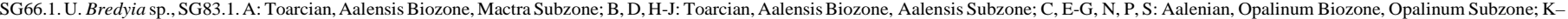
M, O, Q, R, T, U: Aalenian, Opalinum Biozone, Comptum Subzone. Scale bar: $2 \mathrm{~cm}$.

(Tmetoceras) and rare Hammatoceratidae (Bredya and Czerneyiceras) (Fig. 3). No typically Tethysian phylloceratids were found among the 20 species identified (some of which are represented in Fig. 4).

The foraminiferal assemblages recorded along the stratigraphic interval are very abundant and display a high species richness (Figs. 5, 6). A total of 71 species (some of which are represented in Figs. 7, 8), corresponding to 26 genera and five suborders, have been identified, all typical of the Jurassic platforms in the northern hemisphere.

\subsubsection{Upper Toarcian, Aalensis Biozone, Mactra Subzone}

Samples SG1-SG8; $3.5 \mathrm{~m}$ of $0.70 \mathrm{~m}$-thick greyish marls alter- nating with 0.15 m-thick lenticular greyish marly limestones with abundant ammonite content.

Index fossil: Pleydellia mactra (Dumortier).

The ammonite assemblage recognised in this subzone, which corresponds to six fossiliferous levels, reveals low number of specimens (16) but a relatively high number of 


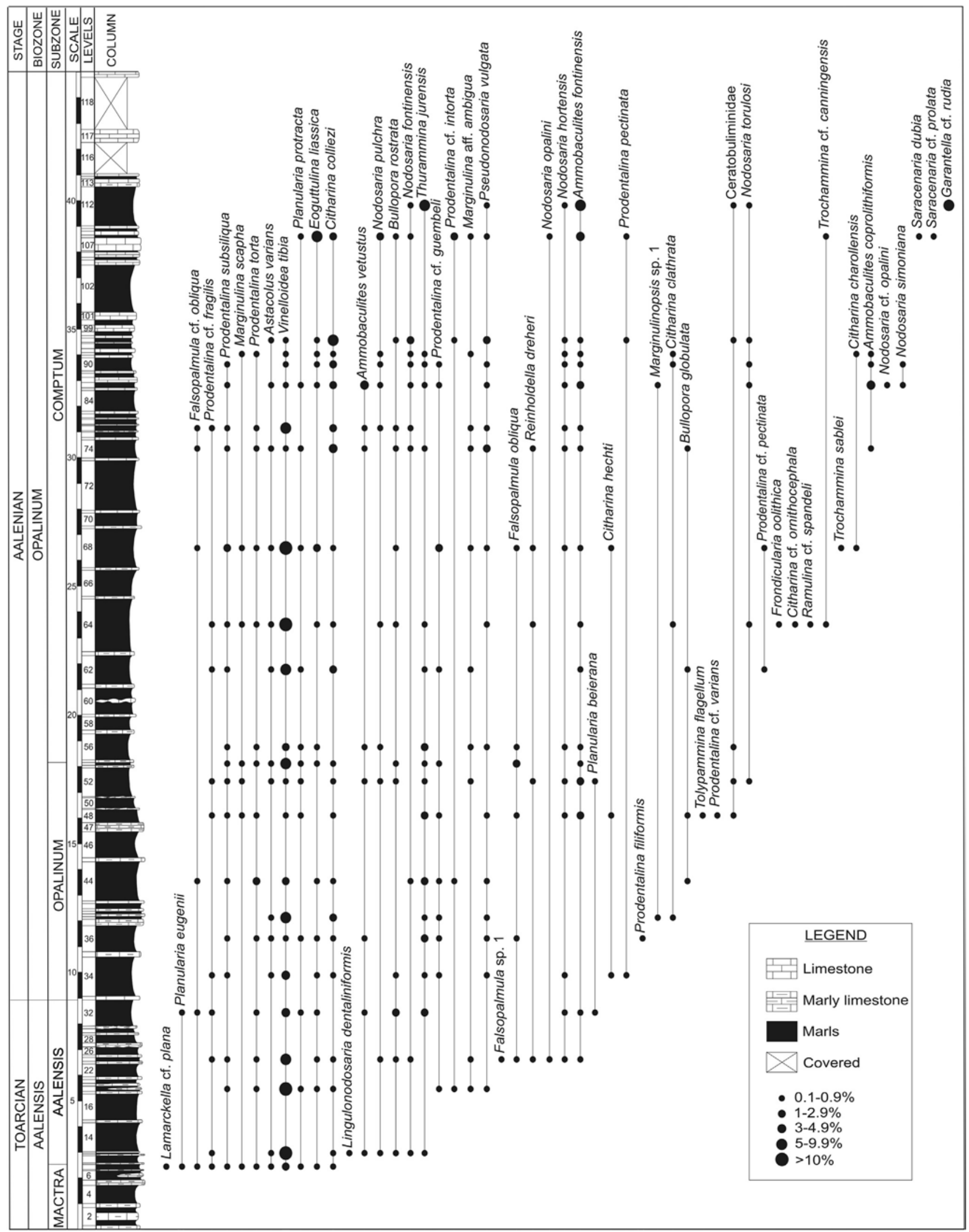

Fig. 5. Occurrence and relative abundance of some of the foraminiferal taxa recorded in the studied stratigraphic interval. 


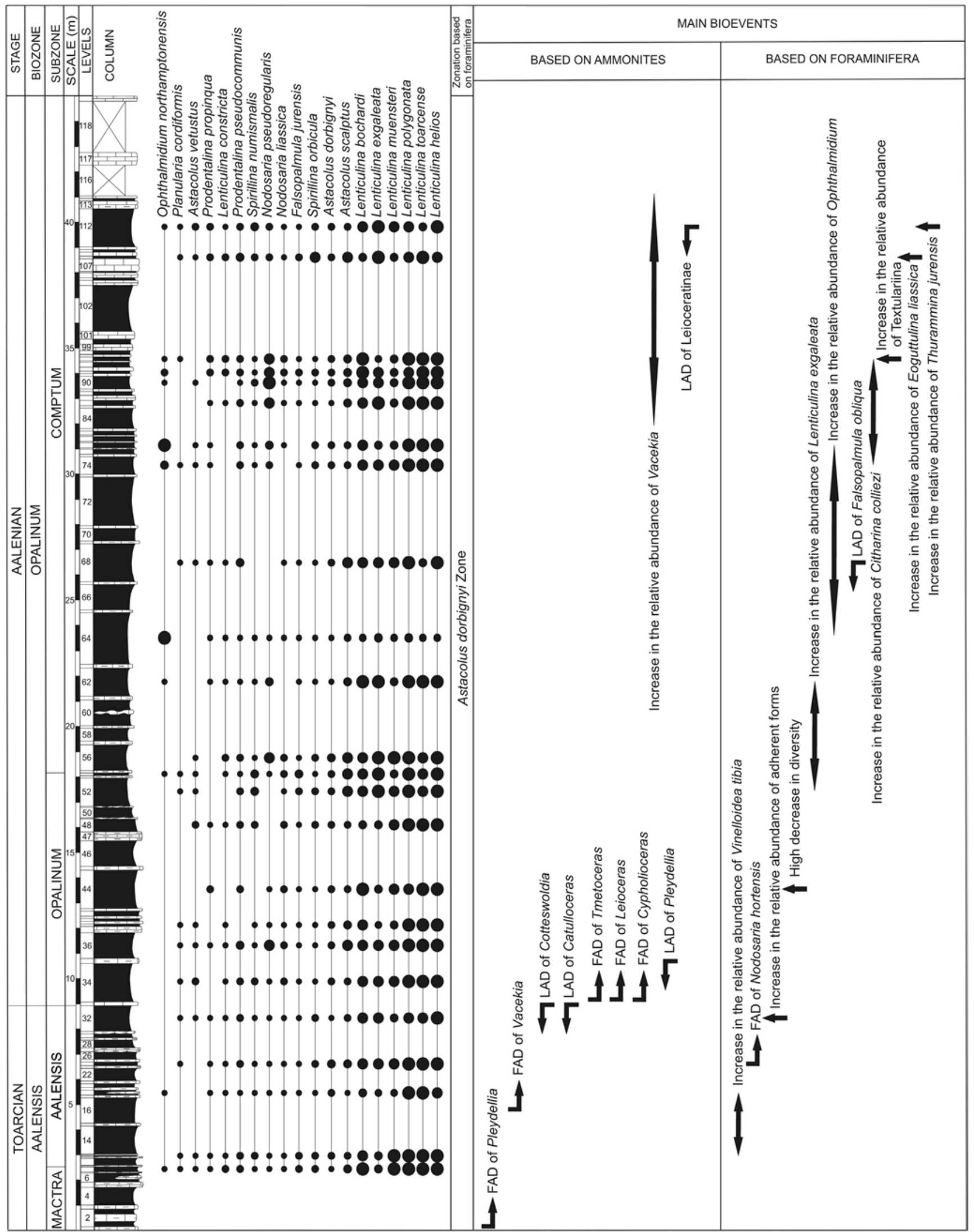

Fig. 6. Occurrence and relative abundance of some of the foraminiferal taxa recorded in the studied stratigraphic interval (left), and main bioevents based on ammonites and foraminifers identified along the lower/middle Jurassic transition in the São Gião section (right). 


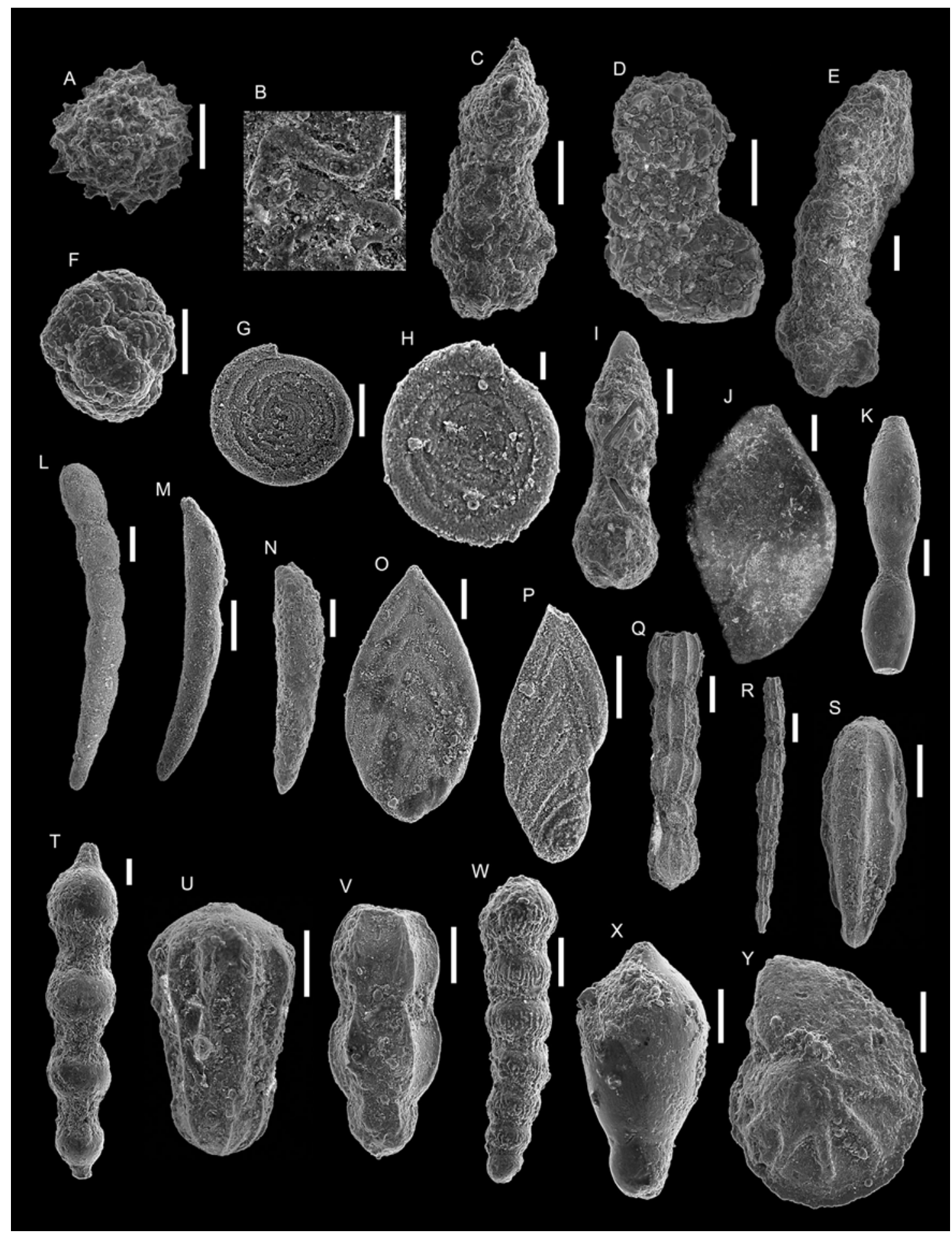

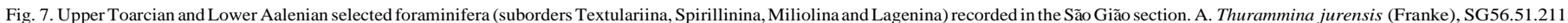

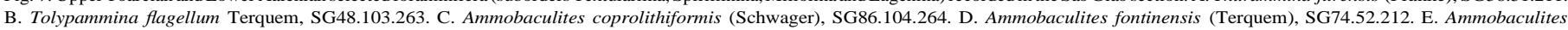

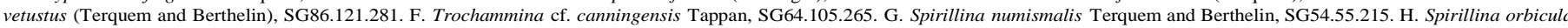

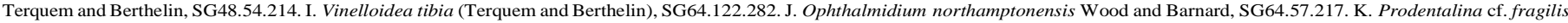

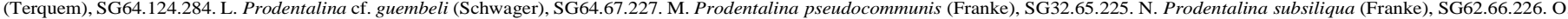

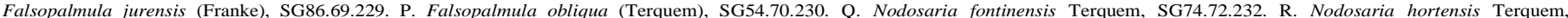

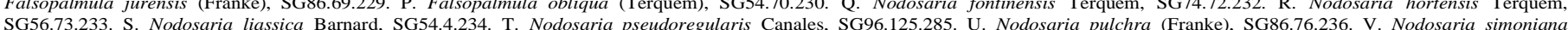

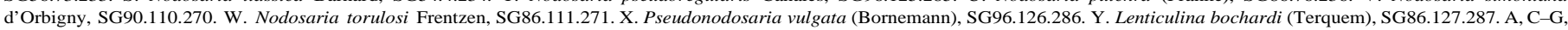
I-L, N-Y: Aalenian, Opalinum Biozone, Comptum Subzone; B, H: Aalenian, Opalinum Biozone, Opalinum Subzone; M: Toarcian, Aalensis Biozone, Aalensis Subzone. Scale bars: 100 mm.

species (five identified species corresponding to two genera). Most specimens correspond to the Cotteswoldia genus, namely $C$. limatula Buckman, C. egena Buckman, and C. costulata (Zieten) (representing 38\% of the identified specimens), and the Pleydellia genus, namely $P$. fluens (Buckman) and $P$. subcompta Branco (also representing $38 \%$ of the identified specimens) (Appendix A, Table S1). The latter is a significant component of the recorded assemblages, as it represents earlier Pleydellia, thus 


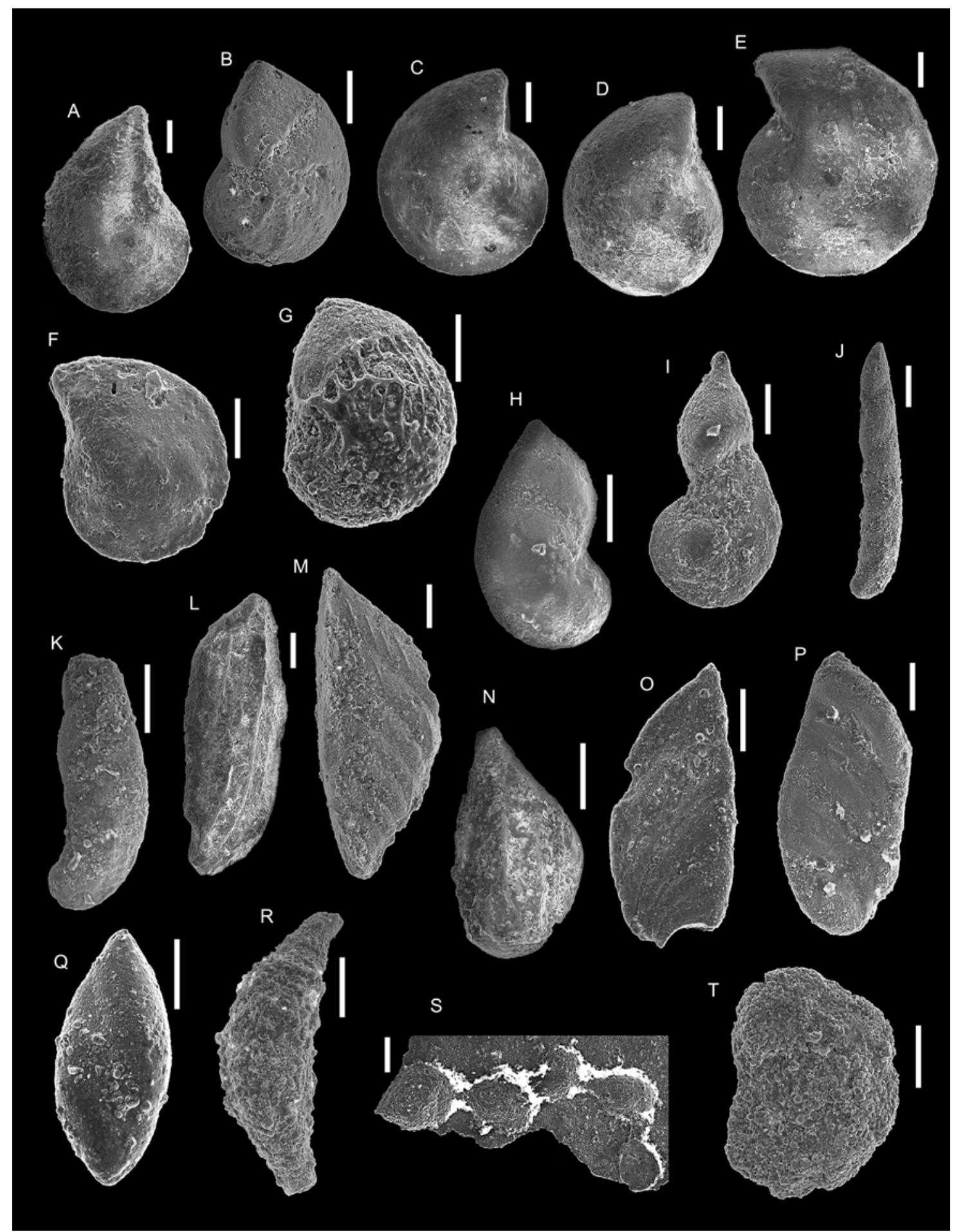

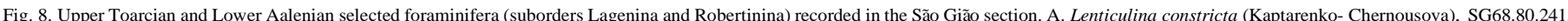

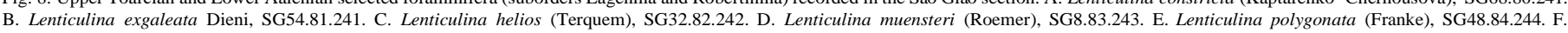

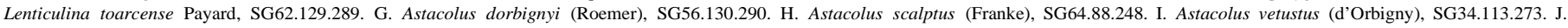

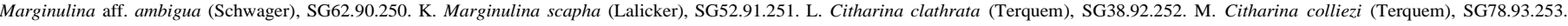

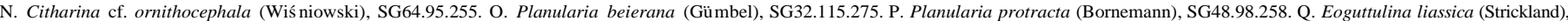

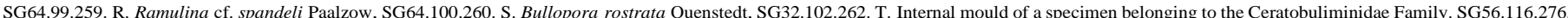

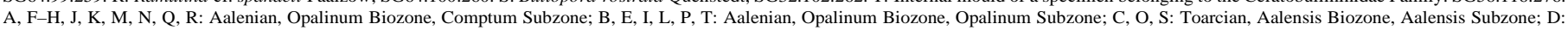
Toarcian, Aalensis Biozone, Mactra Subzone. Scale bars: $100 \mathrm{~mm}$.

characterising the subzone, whose base is recognised by the FAD of these forms.

The only foraminiferal assemblage studied from the Mactra Subzone corresponds to sample SG8 (Table S2). A total of 469 specimens were obtained, 434 (93\%) of which were identified at specific level. Taking into account the number of grams of picked sediment, in this sample the abundance amounts to 60.5 foraminifera per gram of picked sediment. In this assemblage, 
four suborders (Spirillinina, Miliolina, Lagenina and Robertinina) were identified, in which Lagenina was the most abundant (87\%). Spirillinina and Miliolina occur in percentages of less than $4 \%$ and Robertinina is known from a single specimen. The total absence, in this assemblage, of representatives of the Textulariina Suborder is notable, given that these are present, even if in small numbers, in Lower-Middle Jurassic foraminiferal assemblages of other coeval basins(Canalesand Herrero, 1996, 2000; Canales andUreta, 1997; Canales, 2001; Canales and Henriques, 2007, 2008; Figueiredo,

2009; Canales et al., 2010; Figueiredo et al., 2010; Guterres, 2010; Magno, 2010; Figueiredo and Guterres, 2012). At generic level, a total of 13 genera were identified, in which Lenticulina, with a relative abundance of $77 \%$, clearly predominates. On a specific level, a total of 31 species were identified, of which Lenticulina polygonata (Franke) was the most abundant (19\%). There was no evidence of any single species dominating over the others (Table S2).

\subsubsection{Upper Toarcian, Aalensis Biozone, Aalensis Subzone}

Samples SG9-SG33; $7.5 \mathrm{~m}$ of greyish marls with thicknesses varying from 0.15 to $1.10 \mathrm{~m}$, alternating with 0.15 m-thick of bioturbated greyish marly limestones, displaying very abundant, sometime pyritised ammonite internal moulds.

Index fossil: Pleydellia aalensis (Zieten).

Other biostratigraphic units have been proposed for the upper part of the Aalensis Biozone. Page (2003) uses P. fluitans as index for the Fluitans Subzone. However, $P$. fluitans has a scarce record in the Lusitanian Basin and, as pointed by Elmi et al. (1997: p. 34), "'sa position stratigraphique au sein de la zone à Aalensis ne nous paraît pas bien é tablie, ce qui justifie son abandon en tant qu'indice', Concerning the Lugdunensis Subzone, it has been established due to traditional misinterpretations of $P$. aalensis (Zieten) by some authors. According to Elmi et al. (1997: p. 34), “L'é cole française utilisait une sous-zone à Aalensis pour cet intervalle de temps [Sous-zone à Lugdunensis] en faisant référence à l'espèce figurée par Dumortier (1874, pl. L, Fig. 1-3) qui est bien diffé rente du type de Zieten [. . .]. Afin d'é viter de pé renniser les confusions, nous proposons le nouveau nom de Pleydellia (Walk- ericeras) lugdunensis [. . .]" for the French forms of Walkericeras, previously interpreted as $P$. aalensis sensu Dumortier non Zieten, the original author of the aalensis species. But the Aalensis Biozone, based on the occurrence of its index fossil - P. aalensis (Zieten), i.e., specimens displaying rounded umbilical wall and variable ribbing during ontogeny, according to the original interpretation by Zieten (1830) - is perfectly recognizable in several basins around the Iberian Plate, where correlation has been already established (e.g., Goy et al., 2000), including at Fuentelsaz, the Aalenian GSSP.

The ammonite assemblage recognised in the Aalensis Subzone of the Aalensis Biozone, which corresponds to 12 fossiliferous levels, reveals high abundance (140 specimens, 118 of which identified at the species level) and high number of taxa (10 identified species; four identified genera) (Table S3). The base of the subzone is defined by the FAD of the index species $P$. aalensis (Zieten, 1830 non Dumortier, 1874), which dominates amongst the fauna (39 specimens representing 33\% of the identified specimens), in association with $P$. folleata (Buckman). The base of the subzone also records the last occurrence of $P$. subcompta Branco and P. fluens (Buckman). Cotteswoldia costulata (Zieten) (18\% of the identified specimens), C. limatula Buckman and C. egena Buckman, which occur in the previous subzone, still remain here. Last Catulloceras occur together with the first Tmetoceras; Vacekia sourensis (Perrot) and early striate Vacekia, like V. striata Henriques (Sandoval et al., 2012a), are also relatively abundant (10\% of the identified specimens). The marly levels of the thick SG14 bed reveal a great abundance of indeterminate pyritised Cotteswoldia and Pleydellia nucleus (Table S3).
Four foraminiferal assemblages (samples SG12, SG18, SG24 and SG32) from the Aalensis Subzone were studied (Table S4). A total of 2006 specimens were recovered, 1922 of which were identified at the specific level. The average abundance in these assemblages amounts to 94 foraminifera per gram of picked sediment. At suborder level, representatives of Textulariina, Spirillinina, Mili- olina, Lagenina and Robertinina were identified, within which Lagenina was the most abundant (82\% of the assemblage), followed by Miliolina (15\%). This fact is remarkable, since representatives of this suborder, when present in Toarcian-Aalenian foraminiferal assemblages, are usually very rare (Herrero and Canales, 1997; Canales and Herrero, 2000; Canales, 2001; Canales and Henriques, 2007, 2008; Figueiredo, 2009; Figueiredo et al., 2010; Figueiredo and Guterres, 2012). The remaining suborders show relative abundances of less than $2 \%$. At generic level, 18 genera were identified in these assemblages and, again, the representatives of the genus Lenticulina, representing 69\% of the assemblage, were dominant. Moreover, the large amount of specimens correspond- ing to the Vinelloidea genus (Miliolina Suborder), whose relative abundance amounts to $15 \%$, is noticeable. A great number of species (45 in total) have been identified in these assemblages. Among them, Lenticulina toarcense Payard is the most abundant ( $18 \%$ of the assemblage), but no single species was markedly dominant (Table S4).

\subsubsection{Lower Aalenian, Opalinum Biozone, Opalinum Subzone}

Samples SG34-SG54; $8 \mathrm{~m}$ of alternating greyish marly lime- stones in 1 m-thick beds, and thin micritic marly limestones in

$0.20 \mathrm{~m}$-thick beds, including very abundant, sometime pyritised ammonite internal moulds.

Index fossil: Leioceras opalinum (Reinecke).

The ammonite assemblage recognised in this subzone corre- sponds to seven fossiliferous levels, displaying the greatest abundance and species richness in the whole section (153 specimens; 45 identified at species level; six identified species; five identified genera; Table S5). The base of the subzone is characterised by the FAD for Leioceras opalinum (Reinecke), which appears in association with Pleydellia representatives until bed SG35, where the LAD for this taxon is recorded (Fig. 3). P. aalensis (Zieten), P. folleata (Buckman), P. lotharingica (Buckman) and P. fluitans (Dumortier) co-exist at the base with the first Leiocer- atinae, representing $48 \%$ of the total recorded assemblages in this subzone, followed by Vacekia representatives, mainly $V$. striata Henriques (10\%). Cypholioceras lineatum (Buckman), Leioceras opalinum (Reinecke) and indeterminate species of both genera represent only rv11\% of the recorded ammonite specimens. Rare Czerneyiceras also feature in the ammonite assemblages of this unit, in which the LAD of several taxa have been identified namely Pleydellia, Cotteswoldia and Catulloceras - together with the FAD of others - Cypholioceras, Leioceras and Czernyeiceras - corresponding to an important ammonite turnover from the typical Late Toarcian taxa to the characteristic Early Aalenian taxa. This turnover, which can be accurately assigned to the Opalinum Subzone, is particularly well documented by the SG35 assemblage in the São Gião section (Table S5).

Seven foraminiferal assemblages from the Opalinum Subzone were studied (samples SG34, SG36, SG38, SG44, SG48, SG52 and SG54; Table S6). A total of 3285 specimens were recovered, 3012 of which have been identified at the specific level. The average abundance in these assemblages reaches 74 foraminifera per gram of picked sediment. As in the previous subzone, 5 suborders were identified, namely Textulariina, Spirillinina, Miliolina, Lagenina and Robertinina, and again, Lagenina is the dominant suborder (91\%), followed by Miliolina (4\%) and Spirillinina (3\%). The Textulariina and Robertinina are very rare $(<2 \%)$. A total of 19 genera were identified, within which representatives of Lenticulina 
genus still predominate. Within the unit, a total of 53 species were identified, which exceeds the number obtained for the Aalensis Subzone. There is no evidence for the dominance of any single species, although the most abundant is Lenticulina helios (Ter- quem), with a relative abundance of $19 \%$ (Table S6).

\subsubsection{Lower Aalenian, Opalinum Biozone, Comptum Subzone}

Samples SG55-SG119; 28 m-thick of greyish marls of irregular thickness ranging from 0.20 to $2 \mathrm{~m}$, alternating with limestones, which are marly and grey at the base, becoming whiter and more micritic towards the top of the succession.

Index fossil: Cypholioceras comptum (Reinecke).

The ammonite assemblage recognised in this subzone, which corresponds to 20 fossiliferous levels, reveals relatively high number of specimens (138 specimens; 70 identified at the species level) and high number of taxa (8 identified species belonging to four different genera and two indeterminate species, one of Bredyia and another of Czernyeiceras; Table S7). The base of the subzone is defined by the FAD of the fossil index, associated to other species of the Cypholioceras genus - C. opaliniforme (Buckman) and C. lineatum (Buckman), representing 27\% of the identified specimens - and forms of Leioceras ranging from the striated $L$. opalinum (Reinecke) to the costulated L. costosum (Quenstedt), which represent $20 \%$ of the identified specimens. All Leioceratinae disappear at SG107, where the facies abruptly changes to micritic white limestones. Vacekia striata Henriques and V. sourensis (Perrot), as well as Tmetoceras scissum (Benecke) persist within this subzone, the former being quite significant (26\% of the identified specimens) within the unit as a whole, and particularly when Leioceratinae are less abundant or absent (Table S7).

Taking the significant development of the Comptum Subzone in the São Gião section into account, 12 foraminiferal assemblages were studied (samples SG56, SG62, SG64, SG68, SG74, SG78, SG86, SG90, SG92, SG96, SG108 and SG112; Table S8). A total of 7363

specimens were recovered, 7071 of which were identified at specific level. Again, specimens corresponding to the Textulariina, Spirillinina, Miliolina, Lagenina and Robertinina suborders were obtained, with the Lagenina Suborder dominating (76\%). Repre- sentatives of the Miliolina Suborder show a relative abundance of $19 \%$. Again, the representatives of this suborder are more frequent than in coeval Upper Toarcian-Lower Aalenian Iberian sections (Herrero and Canales, 1997; Canales and Herrero, 2000; Canales, 2001; Canales and Henriques, 2007, 2008; Figueiredo, 2009; Figueiredo et al., 2010; Figueiredo and Guterres, 2012). In these assemblages, the representatives of the remaining suborders are

rare and all display relative abundances $<3 \%$, or even $<1 \%$ in the

case of Robertinina. A total of 24 genera were identified, with the representatives of the Lenticulina genus again presenting the highest relative abundance (56\%) and dominating over the remaining genera. The relative abundance of other genera such as Vinelloidea (9\%), Ophthalmidium (9\%), Nodosaria (6\%), Astacolus

(6\%), Prodentalina (4\%) and Ammobaculites (2\%) is also notable, since they were much rarer in previously studied assemblages. Finally, a total of 63 species were identified, of which Lenticulina helios (Terquem) is the most abundant (13\%) (Table S8).

\subsection{Biostratigraphic significance of the recorded assemblages}

The ammoniterecord (447 specimens, 20 species, 9 genera) for the São Gião section has enabled 4 biostratigraphic units to be recognised: the Mactra and Aalensis subzones of the Aalensis Biozone in the Upper Toarcian, and the Opalinum and Comptum subzones of the Opalinum Biozone in the Lower Aalenian (Fig. 3). This biostratigrahic zonal scheme has been already recognised in theLusitanianBasin, as well asin othercoevalbasins of the Iberian Peninsula (Henriques, 1995; Henriques et al., 1996; Sandoval et al., 2001a), namely at the Fuentelsaz section (Iberian Cordillera), where theAalenianGSSPhasbeenestablished(Cresta et al., 2001).

From a biostratigraphic point of view, the benthic foraminifera identified in São Gião (13,116 specimens, 71 species, 26 genera, 5 suborders) allow for the recognition of the Astacolus dorbignyi Zone

- in the sense of the Dorbignyi Zone proposed by Canales (2001) in the BasqueCantabrian Basin (Northern Spain) for the Lower- Middle Jurassic transition - with Astacolus dorbignyi (Roemer) serving as the index fossil (Fig. 6). This zone has also been recognised in other sections of the Lusitanian Basin (Figueiredo, 2009; Guterres, 2010; Magno, 2010; Canales et al., 2010; Figueiredo et al., 2010; Figueiredo and Guterres, 2012). Its lower boundary is marked by the first record of the index species, previously unrecognised in the Lusitanian Basin, whose upper boundary coincides with the first record of Lenticulina quenstedti (Gümbel), the index species for the Lenticulina quenstedti Zone, which has been characterised as belonging to the upper part of the Gigantea Subzone (Bradfordensis Biozone, Middle Aalenian) at the Bajocian GSSP in the Murtinheira section (Portugal) (Canales and Henriques, 2013).

\section{Discussion}

The composition of the ammonite assemblages in the São Gião section is cosmopolitan in nature, with a constant and continuous record of both northwest European taxa - thus allowing the recognition of the standard biozonation established for the Lower- Middle Jurassic transition - together with typical Mediterranean taxa - thus increasing its correlation potential with sections located in both provinces. Both reproduce the general trends already recognised in other coeval sections of the Lusitanian Basin and of the Iberian Plate (Henriques, 1989, 1992, 1995, 2000a, b; Henriques et al., 1996; Goy et al., 2000; Sandoval et al., 2001a; Azerêdo et al., 2003), although the ammonite content displays some peculiarities of stratigraphic and palaeoecological relevance, as discussed below (Sections 6.1 and 6.3).

The general composition of the foraminiferal assemblages recorded in São Gião is also comparable with other coeval sections, not only in the Lusitanian Basin (Canales and Henriques, 2007, 2008; Figueiredo, 2009; Figueiredo et al., 2010; Guterres, 2010; Magno, 2010; Figueiredo and Guterres, 2012), but also in other Iberian sections (Canales and Herrero, 1996, 2000; Canales and Ureta, 1997; Herrero and Canales, 1997; Canales et al., 2000; Canales, 2001). However, like the ammonite fauna, the forami- niferal assemblages display some peculiarities in terms of their species richness and the main components of the assemblages, which are also of stratigraphic and palaeoecological relevance, as discussed below (Sections 6.2 and 6.3).

\subsection{Ammonite record and stratigraphic implications}

With regard to the stratigraphic range of the index species Pleydellia aalensis (Zieten) and Leioceras opalinum (Reinecke), their co-existence at the base of the Opalinum Subzone has been clearly confirmed, corresponding to a bioevent recognisable at basinal scale (Fig. 4 (C)). The base of the Opalinum Subzone therefore has to be established by the FAD of the latter, and not by its FAD concomitant with the LAD of Pleydellia aalensis (Zieten) (Fig. 6). Similarly, the co-occurrence of Leioceras opalinum (Reinecke) and the FAD of Cypholioceras comptum (Reincke) at the base of the Comptum Subzone ignores the extinction of the former as a criterion for recognising the Opalinum-Comptum subzonebound- ary (Fig. 4 (K)).

The increase in the relative abundance of Vacekia representa- tives in the upper part of the Comptum Subzone is a relevant 
bioevent, at least with regional value, allowing the subzone to be recognised in sections of the Lusitanian Basin where the last Leioceratinae representatives are generally rare or absent (Fig. 3).

\subsection{Foraminiferal record and stratigraphic implications}

With regard to benthic foraminifera species richness, a total of 57 species where identified in the stratigraphic interval studied in the Zambujal de Alcaria section (Figueiredo, 2009; Figueiredo et al., 2010), 45 in the Maria Pares section (Guterres, 2010; Figueiredo and Guterres, 2012), and 35 in the Murtinheira section (Canales and Henriques, 2008), all of which lie in the Lusitanian Basin. In addition, a total of 50 species where obtained from different sections of the Basque-Cantabrian Basin in Northern Spain (Canales, 2001). In the Moyuela section, located in the Iberian Range (Spain), 47 species were identified along the Upper Toarcian and Lower Aalenian transition (Canales and Herrero, 2000), whilst in the Fuentelsaz section (Aalenian GSSP), also located in the Iberian Range, a total of 62 species were obtained (Herrero and Canales, 1997). As a consequence, and taking into account the fact that a total of 71 species have been identified in São Gião, this section is the most diverse of the Iberian basins in terms of this stratigraphic interval.

Regarding the taxonomical composition of the assemblages, as commonly occurs in Jurassic foraminiferal assemblages from the Boreal Realm, Lenticulina (Lagenina Suborder) is the most abundant genus. In the São Gião section, the most abundant species of this genus in almost all of the assemblages is L. helios (Terquem). Canales et al. (2010) have pointed out that the different species of Lenticulina recorded in the Lower-Middle Jurassic transition in several sections of the Lusitanian Basin show variations in their relative abundances which can be related to the facies where they developed. Thus, L. muensteri (Roemer) is relatively more abundant in facies corresponding to the deeper part of the platform, whilst $L$. helios (Terquem) reaches maximum relative abundance in the middle platform, and $L$. toarcense Payard is most abundant in facies corresponding to the shallower part (the inner platform).

Other Lagenina genera with unusually high relative abundance, such as Prodentalina, Nodosaria and other elongated forms, corresponding to shallow infaunal morpho-groups and indicating good levels of nutrients and oxygenation in the infaunal microhabitats (Reolid et al., 2012), have been recorded in the Comptum Subzone. The abundant record of representatives of the Miliolina Suborder, which are present in almost all the studied assemblages, and are unusually frequent in the Aalensis and in the upper part of the Comptum subzones, is also notable.

The foraminiferal assemblages recorded are abundant and very diverse. Within the studied time span, there are no significant arrivals or disappearances of taxa - the whole stratigraphic interval corresponds to a single foraminiferal zone: the Astacolus dorbignyi Zone. For this reason, a total of 11 bioevents, based on FAD, LAD or change in the observed abundance of some taxon or in assemblage diversity have been established, representing bios- tratigraphical proxies generally of local application (Fig. 6). Nevertheless, some of them, e.g., the increase in the relative abundance of Lenticulina exgaleata Dieni from the upper part of the Opalinum Subzone to the lower part of the Comptum Subzone, have also been recognised in other coeval sections in theLusitanian Basin(Canales and Henriques, 2008; Figueiredo, 2009; Figueiredo et al., 2010; Guterres, 2010), thus demonstrating regional value. The FAD of Nodosaria hortensis Terquem in the Aalensis Subzone and the marked increase in the relative abundance of Ophthalmi- dium representatives in the lower part of the Comptum Subzone have been also recognised in the Zambujal de Alcaria Section (Figueiredo, 2009; Figueiredo etal.,2010).Theincreaseobservedin the relative abundance of the representatives of the Textulariina Suborder, as well as in Eoguttulina liassica (Strickland) in the upper part of the Comptum Subzone, have also been recognised in the Murtinheira section (Canales and Henriques, 2008).

\subsection{Faunal turnovers and seawater palaeotemperatures}

A previous study on morphological changes observed in ammonites at the Lias-Dogger boundary, questioned the exis- tence of a faunal crisis during the Late Toarcian-Early Aalenian times (Neige et al., 2001). The ammonite composition of the assemblages throughout the Upper Toarcian-Lower Aalenian record for the São Gião section also shows a virtually constant rate of faunal turnover, i.e., no drastic changes in the number of originations and extinctions between ammonite biozones, unlike the coeval record described for the Betic Cordillera. The Toarcian- Aalenian ammonite record is represented in this case by a major faunal turnover which has been correlated with a sea-level

regressive phase (Sandoval et al., 2001b) and relatively low $\mathrm{d}^{13} \mathrm{C}$

values for bulk carbonates in the Upper Toarcian, followed by a moderate positive excursion of the $\mathrm{d}^{13} \mathrm{C}_{\text {carb }}$ in the Comptum Subzone (Sandoval et al., 2008). This "'Comptum cooling event'”

was also noted by Gó mez et al. (2009) for the Basque-Cantabrian Basin (Northern Spain), in relation to a major faunal turnover in the ammonite and foraminiferal records; a seawater temperature

of $15.78 \mathrm{C}$ based on $\mathrm{d}^{18} \mathrm{O}_{\text {bel }}$ has been proposed for this time

interval. Price (2010) proposes a seawater temperature of 15- $228 \mathrm{C}$ for the Early Aalenian with rapid cooling to a minimum of $78 \mathrm{C}$ for the Comptum Subzone based on the positive isotopic

excursion recognised in the $\mathrm{d}^{18} \mathrm{O}_{\text {bel }}$ curves for the Aalenian and

Bajocian of Scotland; he therefore supports the global range of the "Comptum cooling event'. However, the Comptum Subzone of the São Gião section is characterised by the co-occurrence of northwest European Leioceratinae taxa and Mediterranean Grammoceratinae, namely the dominant Vacekia striata Henri- ques, which may amount to $30 \%$ of the total identified specimens within the whole unit, a feature also recognised at basinal scale (Sandoval et al., 2012a).

Among the foraminifers, miliolids, generally interpreted as typical of shallow waters (Copestake and Johnson, 1981; Haynes, 1981; Stam, 1985; Murray, 1989), have a continuous and relatively abundant record in this section. This group amounts to $19 \%$ of the total assemblage from the Comptum Subzone in São Gião, but is rare in the Aalenian GSSP (Herrero and Canales, 1997), and absent in all coeval sections of the Basque-Cantabrian Basin (Canales, 2001) and the Northern Iberian Range (Canales and Herrero, 2000). In the Lusitanian Basin, Miliolina are rare in distal and proximal facies (Canales and Henriques, 2008; Figueiredo, 2009; Figueiredo et al., 2010), but represent $7 \%$ of the relative abundance in intermediate facies (Guterres, 2010; Figueiredo and Guterres, 2012), such as those of the São Gião section. Regarding the taxonomical composition of the foraminiferal assemblages described in the Basque-Cantabrian Basin (Northern Spain), and in relation to the "Comptum cooling event', 14 species present their FAD within this time interval (Gó mez et al., 2009). Most of them, apparently typical of cool waters, are absent in São Gião and, whenever present, record is scarce, both in terms of stratigraphic distribution and relative abundance.

As a consequence, the results obtained from the compositional analysis of the ammonite and foraminiferal assemblages recorded in the São Gião section do not support the inferred cooling trend to minimum seawater temperatures, or the global character of the "Comptum cooling event". Local reasons must be cited in order to justify the warmer seawater temperature trend in the Lusitanian Basin as inferred here from the ammonite and foraminiferal records, specifically in relation to the palaeogeographic location of 
the basin within the context of the opening of the North Atlantic Ocean (García-Frank etal., 2008)and/or the hypothetical connec- tion between Western Tethys and the Eastern Pacific through the Hispanic Corridor (Arias, 2006, 2007; Sandoval et al., 2012a). Hydrothermal activity and/or changes in oceanic circulation patterns are plausible explanations for the occurrence of warmer seawater temperatures in this sector of the Lusitanian Basin, as opposed to the inferred cool seawater accepted for neighbouring basins.

\section{Conclusion}

The first study of the co-occurrence of ammonite and benthic foraminiferal assemblages across the São Gião section (Central Portugal) represents a contribution to the knowledge of this reference section for the Lower-Middle Jurassic boundary in the Lusitanian Basin. The analysis of the macro- and microfossil assemblages in this expanded section, both correlatable with the Aalenian GSSP at the Fuentelsaz section (Iberian Cordillera, Spain; Cresta et al., 2001), improves the calibration of the biostrati- graphic scale for the Lower-Middle Jurassic transition based on these fossil groups, making benthic foraminifera a particularly useful biostratigraphical proxy when ammonites are poorly preserved, scarce or almost impossible to obtain (e.g., in core samples).

A total of 447 well-preserved ammonite specimens and 13,116 foraminifers have been studied and no evidences of taphonomic processes that could change the original assemblages were detected. From a taxonomic point of view, the ammonite record of the São Gião section mainly includes some typical northwest European Grammoceratinae (Catulloceras, Cotteswoldia, Pleydellia) in the Upper Toarcian, and Leioceratinae (Leioceras, Cypholioceras) in the Lower Aalenian, together with typical Mediterranean Grammoceratinae (Vacekia), Tmetoceratinae (Tmetoceras) and rare Hammatoceratidae (Bredya and Czerneyiceras). No typically Tethysian phylloceratids were found among the 20 identified species (corresponding to 9 genera), but the relative abundance of Grammoceratinae throughout the studied time interval is notice- able, namely Vacekia striata Henriques, which accounts for $26 \%$ of the total identified specimens in the Comptum Subzone. Regarding foraminifera, the recorded assemblages are very abundant, being the most diverse in the Iberian Peninsula for this time interval. A total of 71 species, corresponding to 26 genera and 5 suborders have been identified, all typical of the Jurassic platforms of the northern hemisphere. Among the recognised suborders, Lagenina are dominant, Lenticulina being the best represented genus and Lenticulina helios (Terquem) the most abundant species. In addition, representatives of the Miliolina Suborder are also unusually frequent.

The ammonite record of the São Gião section has enabled four ammonitebased biostratigraphic units to be recognised (Mactra and Aalensis subzones of the Aalensis Biozone in the Upper Toarcian, and Opalinum and Comptum subzones of the Opalinum Biozone in the Lower Aalenian). With regard to benthic foraminifera, the taxa identified have enabled the Astacolus dorbignyi Zone to be identified, as well as 11 bioevents based on FAD, LAD, and changes in the relative abundance of certain taxa or changes in species richness in the recorded assemblages. The constant and continuous ammonite record of northwest Eur- opean taxa, together with the typical Mediterranean taxa throughout the section, the relatively high abundance of Miliolina representatives, which are usually interpreted as typical of shallow waters, and the absence of typical cool water forms, do not concur with the inferred cooling of seawater temperatures assigned to the Early Aalenian, ortheglobalnature of the "'Comptum cooling event".

\section{Acknowledgments}

This study has been supported by Projects CGL2011-23947 and CGL201125894(MinisteriodeEducaciónyCiencia,Spain)andfor theGrupodeInvestigació n UCM 910431 (Complutense University, Madrid, Spain). The laboratory work was supported by the Consortium Petrobras-Galp-Partex of Portugal. The authors are grateful to the Centro Nacional de Microscopía Electró nica (Complutense University of Madrid, Spain) for the SEM photo- graphs; to Claudia Magno for her preliminary work on a part of the studied material; to Dr. Mena Schemm-Gregory for her help with the ammonite photography; to Inês Pena dos Reis for the English revision of the text; and to Dr. Gilles Escarguel, Dr. Fabienne Giraud-Guillot, Dr. Pascal Neige and an anonymous reviewer for the scientific revision of the manuscript.

\section{References}

Aguado, R., O’Dogherty, L., Sandoval, J., 2008. Fertility changes in surface waters during the Aalenian (mid-Jurassic) of the Western Tethys as revealed by calcareous nannofossils and carbon-cycle perturbations. Marine Micropaleon- tology 68, 268-285.

Arias, C., 2006. Northern and Southern Hemispheres ostracod palaeobiogeography during the Early Jurassic: possible migration routes. Palaeogeography, Palaeo- climatology, Palaeoecology 233, 63-95.

Arias, C., 2007. Pliensbachian-Toarcian ostracod biogeography in NW Europe: evidence for water mass structure evolution. Palaeogeography, Palaeoclimatol- ogy, Palaeoecology 251, 398-421.

Azerêdo, A.C., Duarte, L.V., Henriques, M.H., Manuppella, G., 2003. Da dinâmica continental no Triásico aos mares no Jurássico Inferior e Médio. Cadernos de Geologia de Portugal, Instituto Geológico e Mineiro, Lisboa.

Barbosa, B.P., Soares, A.F., Rocha, R.B., Manupella, G., Henriques, M.H.P., 1988. Carta Geoló gica de Portugal na escala de 1:50 000. Notícia explicativa da folha 19A - Cantanhede. Serv. Geol. Portugal, Lisboa.

Barbosa, B.P., Soares, A.F., Rocha, R.B., Manupella, G., Henriques, M.H.P., 2008. Carta Geológica de Portugal na escala de 1:50 000. Notícia explicativa da folha 19A-Cantanhede. Dep. Geologia, Inst. Nac. Engenharia, TecnologiaeInovação, Lisboa.

Caloo-Fortier, B., 1985. La ligne de suture 'e le' ment de comparaison des genres Pleydellia, Vacekia, Leioceras (Hildocerataceae), Toarcien-Aale' nien, S. Gĩ̃ao, Portugal. Colloque CIEL. Cahiers de l'Institut Catholique de Lyon 14, 231-253. Canales, M.L., 2001. Los foraminí feros del Aaleniense (Juŕa sico Medio) en la Cuenca Vasco-Cant'a brica (N de Espa ñ a). Revista Espa ̃n olad e Micropaleontología 33(3) 253-438.

Canales, M.L., Henriques, M.H., 2007. Análisis cuantitativo de los foraminíferos del Aaleniense (Jurásico Medio) de la sección de Murtinheira (Cabo Mondego, W de Portugal). Consideraciones paleoecológicas. In: Carvalho, I.S., Cassab, R.C.T., Schwanke, C., Carvalho, M.A., Fernandes, A.C.S., Rodrigues, M.A.C., Carvalho, M.S.S., Arai, M., Oliveira, M.E.Q. (Eds.), Paleontologia: Cenários de Vida, vol. 2. Editora Interciência, Rio de Janeiro, pp. 383393.

Canales, M.L., Henriques, M.H., 2008. Foraminifera from the Aalenian and the Bajocian GSSP (Middle Jurassic) of Murtinheira section (Cabo Mondego. West Portugal): biostratigraphy and paleoenvironmental implications. Marine Micropaleontology 67, 155-179.

Canales, M.L., Henriques, M.H., 2013. Foraminiferal assemblages from the Bajocian Global Stratotype Section and Point (GSSP) at the Cape Mondego (Portugal). Journal of Foraminiferal Research 43, 182-206.

Canales, M.L., Henriques, M.H., Ureta, M.S., 2000. Aná lisis de las asociaciones de foraminíferos del Aaleniense en los má rgenes oriental y noroccidental de la Placa Ibé rica: implicaciones biogeográficas y bioestratigráficas, Actas do I Congresso Ibérico de Paleontología/XVI Jornadas de la Socociedad Española de Paleontología, 8-9.

Canales, M.L., Henriques, M.H., Figueiredo, V.L., Guterres, H., 2010. Foraminifera from the LowerMiddle Jurassic of the Lusitanian Basin (Portugal) - biostrati- graphic and palaeoecological significance. In: Pena dos Reis, R., Pimentel, N. (Eds.), Rediscovering the Atlantic: new ideas for an old sea. ... II Central \& North Atlantic Conjugate Margins Conference Lisbon, 2010, pp. $42-46$.

Canales, M.L., Herrero, C., 1996. Aná lisis de la diversidad en las asociaciones de foraminíferos del Aaleniense (Jurá sico) en Cillamayor y San andré s (Cuenca Vasco-Cantá brica). Tomo Extraordinario. 125 Aniversario de la Real Sociedad Española de Historia Natural, 291-294. 
Canales, M.L., Herrero, C., 2000. Asociaciones de foraminíferos del Toarciense superior y Aaleniense en la secció n de Moyuela (Zaragoza, Españ a). Revista Españ ola de Micropaleontología 32, 301-317.

Canales, M.L., Ureta, S., 1997. Asociaciones de ammonoideos y foraminíferos del Aaleniense en la sección de Castillo Pedroso (Cuenca Vasco-Cantábrica, España). Les Cahiers de l’Université Catholique de Lyon 10, 19-33.

Copestake, P., Johnson, B., 1981. The Hettangian to Toarcian (Lower Jurassic). In: Jenkins, D.G., Murray, J.W. (Eds.), Stratigraphic Atlas of Fossil Foraminifera. Ellis Horwood Limited, pp. 129188.

Cresta, S., Goy, A.,Ureta, S., Arias, C., Barron, E.,Bernad, J.,Canales, M.L.,Garcia-Joral, F., García-Romero, E., Gialanella, P.R., Gomez, J.J., Gonzalez, J.A., Herrero, C., Martinez, G., Osete, M.L., Perilli, N., Villalain, J.J., 2001. The Global Boundary Stratotype Section and Point (GSSP) of the Toarcian-Aalenian boundary (Lower- Middle Jurassic). Episodes 24, 166-175.

Dumortier, E., 1874. In: Savy, F. (Ed.), Études paléontologiques sur les dépôts jurassiques du Bassin du Rhône, Paris.

Ellis, B.F., Messina, A., 1940-1990. Catalogue of Foraminifera. Museum of Natural History, New York.

Elmi, S., Rulleau, L., Gabilly, J., Mouterde, R., 1997. In: Cariou, E., Hantzpergue, P. (Eds.), Toarcien. Biostratigraphie du Jurassique ouest-europé en et mé diterran- é en: zonations parallè les et distribution des inverté bres et microfossiles. Bulletin du Centre de Recherches Elf Exploration Production 17, 25-36.

Ferná ndez Ló pez, S., Henriques, M.H., Linares, A., Sandoval, J., Ureta, M.S., 1999a. Aalenian Tmetoceras (Ammonoidea) from Iberia. Taxonomy, habitats, and evo- lution. In: Oló riz, F., Rodríguez-Tovar, F.J. (Eds.), Advancing Research on Living and Fossil Cephalopods. Kluwer Academic/Plenum Publishers, pp. 91-108.

Ferná ndez Ló pez, S., Henriques, M.H., Linares, A., Sandoval, J., Ureta, M.S., 1999b. Aalenian Tmetoceras (Ammonoidea) from Iberia. Taphonomy and palaeobio- geography. In: Oló riz, F., Rodríguez-Tovar, F.J. (Eds.), Advancing research on living and fossil cephalopods. Kluwer Academic/Plenum Publishers, pp. 395-417.

Fernández López, S., Meléndez, G., 1995. Phylloceratina ammonoids in the Iberian Basin during the Middle Jurassic: a model of biogeographical and taphonomical dispersal related to relative sealevel changes. Paleogeography, Palaeoclima- tology, Palaeoecology 120, 291-302.

Fernández Ló pez, S., Duarte, L.V., Henriques, M.H., 2000. Ammonites from lumpy limestones in the Lower Pliensbachian of Portugal: taphonomic analysis and palaeoenvironmental implications. Revista de la Sociedad Geológica de España 13, 3-15.

Figueiredo, V.L., 2009. Foraminíferos da passagem Jurássico Inferior - Médio do Sector Central da Bacia Lusitânica: o perfil de Zambujal de Alcaria, Ms. C. thesis. Universidade de Coimbra, Portugal (Unpublished)

Figueiredo, V.L., Henriques, M.H., Canales, M.L., 2010. Foraminíferos bentonicos da passagem Jurá ssico Inferior-Mé dio do sector central da Bacia Lusitânica: o perfil de Zambujal de Alcaria. B. Geoci. Petrobras 19, 207-231.

Figueiredo, V.L., Guterres, H.C., 2012. Análise quantitativa das associações de foraminiferos da passagem Jurássico Inferior-Médio do perfil de Maria Pares (Setor Norte da Bacia Lusitânica, Portugal) - implicações paleoecológicas. In: Lopes, F.C., Andrade, A.I., Henriques, M.H., Quinta-Ferreira, M., Barata, M.T., Pena dos Reis, R. (Eds.), Para Conhecer a Terra: Memórias e Notícias de Geociências no Espaço Lusófono. Imprensa da Universidade de Coimbra, pp. 151-159.

García-Frank, A., Ureta, S., Mas, R., 2008. Aalenian pulses of tectonic activity in the Iberian Basin, Spain. Sedimentary Geology 209, 15-35.

Gó mez, J.J., Canales, M.L., Ureta, S., Goy, A., 2009. Palaeoclimatic and biotic changes during the Aalenian (Middle Jurassic) at the southern Laurasian Seaway (Bas- que-Cantabrian Basin, northern Spain). Palaeogeography, Palaeoclimatology, Palaeoecology 275, 14-27.

Goy, A., Henriques, M.H., Sandoval, J., Ureta, S., 2000. Stratigraphic events at the Lias-Dogger boundary in Iberia: Betic and Iberian Cordilleras and Lusitanian Basin. "Les événements du passage Lias-Dogger”, Sé ance spé cialisé e de la Societé Gé ologique de France, du Comité Français de Stratigraphie et de l'Association des Gé ologues du Sud-Ouest, Toulouse (França). Strata Série $110,133-136$.

Guterres, H.C., 2010. Foraminíferos do limite Jurássico Inferior-Médio do Sector Norte da Bacia Lusitânica: o perfil de Maria Pares (Rabaçal). Ms.C. thesis. Universidade de Coimbra, Portugal (Unpublished)

Haynes, J.R., 1981. Foraminifera. Macmillan Publishers Ltd, London.

Henriques, M.H., 1989. O limite Lias-Dogger no Baixo Mondego (Portugal) - Ensaio de caracterizac, ao biostratigrá fica. Memº rias e Notícias. Publica, , ao do Museu e Laborat'o rio Mineral'o gico e Geolo' gico da Universidade de Coimbra 107, 37-42. Henriques, M.H., 1992 Biostratigrafia e Paleontologia (Ammonoidea) do Aaleniano em Portugal (Sector Setentrional da Bacia L usitaniana). Ph.D. thesis. Universidade de Coimbra, Portugal (Unpublished).

Henriques, M.H., 1995. Les faunes d'ammonites de l'Aalénien Portugais: composi- tion et implications paléobiogéographiques. In: Gayet, M., Courtinat, B. (Eds.), FirstEuropean Paleontological Congress, Lyon1993. Geobios M.S.18,229-235.

Henriques, M.H., 2000a. Biostratigraphie (Ammonoidea) du passage Lias-Dogger dans le Bassin Lusitanien: la coupe de S. Gião(Portugal). "Les événements du passage Lias-Dogger”, Séance spécialisée dela SocietéGéologique deFrance, du Comité Français de Stratigraphie et de l’Association des Gé ologues du Sud- Ouest, Toulouse (França). Strata Série 1 10, 31-35.

Henriques, M.H., 2000b. Aalenian of the Zambujal de Alcaria section (Central Lusitanian Basin; Portugal). In: Hall, R.L., Smith, P.L. (Eds.), Advances in Jurassic Research 2000, GeoResearch Forum, 6. Transtec Publications, pp. 85-94.

Henriques, M.H., Linares, A., Sandoval, J., Ureta, M.S., 1996. The Aalenian in the Iberia (Betic, Lusitanian and Iberian Basins). In: Riccardi, A.C. (Ed.), Advances in Jurassic Research, GeoResearch Forum, vol. 1-2. Transtec Publications, pp. 139-150.

Henriques, M.H., Perilli, N., 2000. Aalenian nannofossils of São Gião and Serra da Boa-Viagem sections (Lusitanian Basin Portugal): preliminary results, Actas do I Congresso Ibé rico de Paleontología/XVI Jornadas de la Socociedad Española de Paleontología, pp. 93-94.

Herrero, C., Canales, M.L., 1997. Diversidad en los foraminíferos del trá nsito Toarciense/Aaleniense en la secció n de Fuentelsaz (Cordillera Ibé rica). Revista Españ ola de Paleontología 12, 233-242.

Herrero, C., Canales, M.L., 2002. Taphonomic processes in selected Lower and Middle Jurassic foraminifera from the Iberian Range and Basque-Cantabrian Basin (Spain). Journal of Foraminiferal Research 32, 22-42.

Loeblich, A.R., Tappan, H., 1988. Foraminifera genera and their classification. Van Nostrand Reinhold Company, New York970 (2 vol.).

Magno, C., 2010. Foraminíferos do limite Jurássico inferior-médiodo sector Norte da Bacia Lusitânica: o perfil de S. Gião. Ms.C. thesis. Universidade de Coimbra, Portugal (Unpublished).

Magno, C., Henriques, M.H., Canales, M.L., 2008. In: Henriques, M.H., Lopes, F.C., Catarino, L., Duarte, L.V., Rodrigues, N., Andrade, A.I. (Eds.), Foraminíferos do Aaleniano (Jurássico Mé dio) da Ibéria: Bacias Lusitânica (Portugal), Basco- Cantábrica (Espanha) e Cordilheira Ibérica (Espanha), Conferência Internacional "As Geociências no Desenvolvimento das Comunidades Lusófonas”, Universi- dade de Coimbra, Memórias e Notícias, Coimbra 3 (Nova Série), pp. 115-122.

Mouterde, R., Rocha, R.B., Ruget, C., Tintant, H., 1979. Faciès biostratigraphie et paléogéographie du jurassique portugais. Ciências da Terra, Universidade Nova de Lisboa. 29-52, vol. 5.

Murray, J.W., 1989. An outline of faunal changes through the Phanerozoic. In: Jenkins, D.G., Murray, J.W. (Eds.), Stratigraphical Atlas of Fossil Foraminifera, second edition. Ellis Horwood Limited, Hemel Hempstead, pp. 570-573.

Neige, P., Elmi, S., Rulleau, L., 2001. Existe-t-il une crise au passage Lias-Dogger chez les ammonites ? Approche morphomé trique par quantification de la disparité morphologique. Bulletin de la Société géologique de France 172, 125-132.

O’Dogherty, L., Sandoval, J., Bartolini, A., Bruchez, S., Bill, M., Guex, J., 2006. Carbon- isotope stratigraphy and ammonite faunal turnover for the Middle Jurassic in the Southern Iberian palaeomargin. Palaeogeography, Palaeoclimatology, Palaeoecology 239, 311-333.

Page,K.N., 2003. TheLowerJurassic ofEurope:itssubdivisionandcorrelation.Geol. Surv. Den. Greenl. Bull. 1, 23-59.

Price, G.D., 2010. Carbon-isotope stratigraphy and temperature change during the Early-Middle Jurassic (Toarcian-Aalenian), Raasey, Scotland, UK. Palaeogeogra- phy, Palaeoclimatology, Palaeoecology 285, 255-263.

Reolid, M., Sebane, A., Rodríguez-Tovar, F.J., Marok, A., 2012. Foraminiferal mor- phogroups as a tool to approach the Toarcian Anoxic Event in the Western Saharan Atlas (Algeria). Palaeogeography, Palaeoclimatology, Palaeoecology 323-325, 87-99.

Sandoval, J., Henriques, M.H., Ureta, S., Goy, A., Rivas, P., 2001a. The Lias/Dogger boundary in Iberia: Betic and Iberian cordilleras and Lusitanian basin. Bulletin de la Socié té Géologique de France 72, 387-395.

Sandoval, J., O’Dogherty, L., Guex, J., 2001b. Evolutionary rates of Jurassic ammo- nites in relation to sea-level fluctuations. Palaios 16, 311-335.

Sandoval, J., O’Dogherty, L., Aguado, R., Bartolini, A., Bruchez, S., Bill, M., 2008. Aalenian carbon-isotope stratigraphy: calibration with ammonite, radiolarian and nannofossil events in the Western Tethys. Palaeogeography, Palaeoclima- tology, Palaeoecology 267, 115-137.

Sandoval, J., Henriques, M.H., Chandler, R., Ureta, S., 2012a. Latest Toarcian-earliest Bajocian (Jurassic) Grammoceratinae (Hildoceratidae, Ammonitina) of the western Tethys: their palaeobiogeographic and phylogenetic significance. Geo- bios 45, 109-119.

Sandoval, J., Bill, M., Aguado, R., O’Dogherty, L., Rivas, P., Morard, A., Guex, J., 2012b. The Toarcian in the Subbetic Basin (southern Spain): bio-events (ammonite and calcareous nannofossils) and carbon-isotope stratigraphy. Palaeogeography, Palaeoclimatology, Palaeoecology 342-343, $40-63$.

Stam, B., 1985. Quantitative analysis of Middle and Late Jurassic foraminifera from Portugal and its implications for the Grand Banks of Newfoundland. Utrecht Micropaleontological Bulletins $34,1-168$

Zieten, C.H., 1830. Die versteinerungen Wurttembergs, oder naturgetreue abbil- dungen der in den vollstandigsten sammlungen, natmentlich der in dem kabinet des oberamt-arzt Dr. Hartmann befindlichen petrefacten, mit angabe der gebirgsformationen, in welchen dieselben vorkommen und der fundorte. Verlag \& Lithographie der Expedition des Werkes Unsere Zeit (Eds.), Stuttgart. 